\title{
Effects of Silicon, Copper and Zinc Applications on Sheath Blight Disease Severity on Rice
}

\author{
Ei Ei Khaing ${ }^{1}$, Zainal Abidin Mior Ahmad ${ }^{1, *}$, Wong MuiYun ${ }^{1,2}$, Mohamad Razi Ismail, \\ ${ }^{1}$ Department of Plant Protection, Faculty of Agriculture, Universiti Putra Malaysia \\ ${ }^{2}$ Institute of Tropical Agriculture, Universiti Putra Malaysia \\ ${ }^{3}$ Department of Crop Science, Faculty of Agriculture, Universiti Putra Malaysia \\ *Corresponding author: zainalma@upm.edu.my
}

Received October 23, 2014; Revised November 12, 2014; Accepted December 24, 2014

\begin{abstract}
Rice (Oryza sativa L.) sheath blight disease is one of the most important diseases globally which makes its management very difficult. Severe soil micronutrients deficiency and high dosage of nitrogen fertilizer leading to the development of sheath blight disease has become a constraint in rice production in Malaysia. The study was conducted to compare between MR219 and MR253 rice varieties to sheath blight inoculations and micronutrient applications and to determine the impact of disease on rice yield. Sheath blight epidemics in pots were initiated by inoculation at maximum tillering growth stage under glasshouse conditions in April 2013. Silica gel, copper sulphate and zinc sulphate were applied to the soil prior to planting at the rates of $360 \mathrm{~g}, 0.30 \mathrm{~g}, 0.45 \mathrm{~g}$ per $15 \mathrm{~kg}$ soil respectively. Inoculation significantly $(\mathrm{P}=0.05)$ increased sheath blight severity and incidence which caused yield losses of $11 \%$ in moderately resistant variety MR219 and 50\% in moderately susceptible variety MR253. Micronutrients application reduced sheath blight incidence and severity regardless of varieties. Fertilization with Si was significantly more effective than $\mathrm{Cu}$ and $\mathrm{Zn}$ treatments in minimizing yield loss due to sheath blight in both varieties.
\end{abstract}

Keywords: silicon, copper, zinc, sheath blight disease, grain yield

Cite This Article: Ei Ei Khaing, Zainal Abidin Mior Ahmad, Wong MuiYun, and Mohamad Razi Ismail, "Effects of Silicon, Copper and Zinc Applications on Sheath Blight Disease Severity on Rice.” Journal Name, vol. 2, no. 6 (2014): 309-314. doi: 10.12691/wjar-2-6-11.

\section{Introduction}

Sheath blight disease caused by Rhizoctonia solani Kuhn (Teleomorph: Thanatephorus cucumeris), anastomosis group 1 IA (AG1-IA) is an economically important rice disease in all rice growing areas of the world, especially under intensive production [1]. The disease is soil-borne causing up to $25 \%$ of yield losses and is a major disease of rice affecting $50 \%$ of all global rice production countries [2,3,4]. Symptoms of sheath blight include lesions on the base of the leaf sheath near the water line which are elliptical or oval-shaped and greenish-gray with yellow margins [5,6]. Under favorable conditions, sheath blight caused up to a $50 \%$ decrease in yield losses each year worldwide [7]. Unfortunately, at present, there is no known rice varieties with complete resistance to sheath blight [8] and other suitable economic disease management measures are not available [9].So far control of the disease has relied mainly on the use of fungicides when affordable by farmers [10]. Applying fungicide to control the disease is neither economical nor environmentally friendly and there is a potential risk for emergence of pathogen populations that are resistant to fungicides.
In Malaysia, rice is planted as upland rice or wet paddy conditions with farmers practicing double cropping of high-yielding varieties such as MR219 or MR220 [11]. Various nutritional disorders may be encountered in irrigated rice ecosystem. Rice production in Malaysia is focused in these irrigated areas to achieve the target selfsufficiency level of $100 \%$ by 2015 [12]. Long-term intensive cropping with high-yielding varieties on the same land has altered soil micronutrients availability [13]. Severe soil micronutrients deficiency was reported to be associated with rice production in the main granary areas in Malaysia [14]. Balanced nutrition does not only help to achieve better yield in crop production but also allows plants to protect themselves from disease infections $[15,16]$. While Malaysian farmers apply nitrogen $(\mathrm{N})$, phosphorus( $\mathrm{P})$ and potassium( $\mathrm{K}$ ) fertilizers widely, it is found that the applications of micronutrients such as $\mathrm{Zn}$, $\mathrm{Cu}, \mathrm{Mn}$ and $\mathrm{B}$ are not the usual practice [17]. Micronutrient deficiencies are markedly increased due to intensive cropping, loss of fertile top soils and nutrients through leaching and surface runoff [18]. Therefore, the disease management approach emphasized here is to manipulate host plant resistance cultural practices, and application of micronutrients for disease management [19]. Efficacy of micronutrients against sheath blight has been reported [20,21,22]. 
Silicon ( $\mathrm{Si}$ ) is the second most abundant mineral element in soil and has important role in alleviating various environmental stresses and enhancing plant resistance against pathogen [23].Application of complete Si fertilizer not only increases rice yield but also decreases the incidence of rice fungal diseases [24,25]. Effects of silicon on yield are related to the deposition of the element under the leaf epidermis contributing to a physical mechanism of defense; reduce lodging, increases photosynthesis capacity and decreases transpiration losses [26]. Zinc (Zn) is essential for several biochemical processes in the rice plant, such as cytochrome and nucleotide synthesis, auxin metabolism, chlorophyll production, enzyme activation, and membrane integrity [27]. Numerous researches [28,29,30,31] were conducted on $\mathrm{Zn}$ applications in rice crop contributing to increase in grain yield. A balanced Zn application was found to increase the phenol contents of plant and reducing the severity of rice sheath blight [32]. Copper (Cu) fertilization had decreased the severity of a wide range of fungal and bacterial diseases associated by cell wall stability and lignification in plants [33]. Copper plays vital role in the formation of chlorophyll and the increment is positively related with the increase in yield and fruits produced [34]. Studies on improving yield of rice affected by sheath blight disease in Malaysia have not been done. Therefore, the objective of this study was to determine the effects of silicon, copper and zinc applications on sheath blight severity to increase yield and the effects between MR219 and MR253 rice varieties were compared.

\section{Materials and Methods}

\subsection{Plant Materials and Cultivation}

Varieties of rice (Oryza sativa L.) viz MR 219 and MR253 released by Malaysian Agriculture Research and Development Institute MARDI were chosen in this experiment because they are the most widely cultivated and high yielding rice varieties in Malaysia. Experiments were conducted under glasshouse conditions from February to June of 2013 at the research complex, University Putra Malaysia. The soil used was collected from a rice field located in Tanjong Karang, Selangor with the following characteristics: Al $0.17 \mathrm{cmolckg}^{-1}$; $\mathrm{Cu} 0.15$ $\mathrm{mg} \mathrm{kg}{ }^{-1}$, Zn $1.06 \mathrm{mg} \mathrm{kg}^{-1}$, Fe $43.18 \mathrm{mg} \mathrm{kg}^{-1}$ and Mn 3.94 $\mathrm{mg} \mathrm{kg}^{-1}$; Si $4.34 \mathrm{mg} \mathrm{kg}^{-1}$. The soil type was silty clay soil classified as fine textured by USDA Soil Taxonomy System (pH 4.87, clay 49.19\%, silt 43.44\%, sand 7.36\%, cation exchanged capacity [CEC] $1.54 \mathrm{~mol} \mathrm{lit}^{-1}$ ). Rice seeds were soaked in water for $24 \mathrm{~h}$ and dried for another $24 \mathrm{~h}$ at room temperature to hasten germination. Germinated seeds were planted into plastic seedling boxes $(22.7 \mathrm{~cm} \times 18.6 \mathrm{~cm} \times 6.9 \mathrm{~cm})$. Seedlings of 12 days old were uprooted carefully from the nursery tray and transplanted to the well prepared experimental pots $(35 \mathrm{~cm}$ diameter, $38 \mathrm{~cm}$ depth) containing $15 \mathrm{~kg}$ of the paddy soil and placed in the glasshouse. No modifications were made to the pots to allow for drainage, and plants were kept under flooded conditions until the end of the experiment. All the pots were applied nitrogen $(\mathrm{N})$, phosphorus $(\mathrm{P})$ and potassium $(\mathrm{K})$ fertilizers according to the recommended rate. Applications of nitrogen fertilizers
(150 kg N ha ${ }^{-1}$ ) as urea split into 3 times at 15 days after planting (DAP) (25\%), 35 DAP (30\%) and 55 DAP (45\%). Phosphorus (90 kg $\mathrm{P}_{2} \mathrm{O}_{5} \mathrm{ha}^{-1}$ ) as rock phosphate and potassium (150 kg K $\mathrm{O} \mathrm{ha}^{-1}$ ) as muriate of potash applied at basal and at panicle initiation stage at 55DAP.

\subsection{Silicon, Copper and Zinc Application}

Granular silica gel (Classic Chemicals Sdn Bhs, Malaysia) with a minimum $\mathrm{SiO}_{2}$ content of $95 \%$ and particle size ranging from $(0.6-2 \mathrm{~mm}), \mathrm{Cu}$ source as copper sulphate $\left(\mathrm{CuSO}_{4} \cdot 5 \mathrm{H}_{2} \mathrm{O}\right)$ with $99 \%$ purity and $\mathrm{Zn}$ source as zinc sulphate $\left(\mathrm{ZnSO}_{4} .7 \mathrm{H}_{2} \mathrm{O}\right)$ were used in this study. Silica gel, copper sulphate and zinc sulphate were applied to the soil prior to planting at the rates of $360 \mathrm{~g}$, $0.30 \mathrm{~g}, 0.45 \mathrm{~g}$ per $15 \mathrm{~kg}$ soil respectively, as compared to the inoculated and un-inoculated (control) treatment without incorporation of these supplements.

\subsection{Experimental Design}

Treatments were replicated four times in a randomized complete block design with a factorial arrangement of two rice cultivars and five sheath blight pathogen inoculations and fertilizer combinations. Each replication corresponds to three rice plants per experimental unit. Sheath blight inoculation and fertilizer treatment combinations included the following: non-inoculated and untreated (control), inoculated and untreated (control), inoculated and silicon application, inoculated and copper application and inoculated and zinc application.

\subsection{Plant Inoculation}

A virulent isolate of $R$. solani (AG-1 IA), collected from symptomatic rice plants was used for inoculation. Inoculum was obtained as follows: the isolate of $R$. solani was grown on potato dextrose agar (PDA) and incubated for five days at room temperature to produce mycelia. At maximum tillering stage (60DAP), the plants were inoculated with five- day- old mycelia plug of $R$. solani placed on the stem on one cm below the axil of the fully mature leaf and wrapped with paraffin. Immediately after inoculation, all plants were transferred to a moist chamber with 90-96\% relative humidity for one week. The temperature and relative humidity were measured using a traceable relative humidity/temperature meter (Fisher Scientific, Atlanta, GA) and recorded three times per day.

\subsection{Disease Assessment and Yield Determination}

Pots were evaluated for sheath blight development approximately 1 week before maturity and the disease intensity was determined by Highest Relative Lesion Length (HRLH) using the scale of Standard Evaluation System for rice by International Rice Research Institute [35]. At the same time, disease incidence was determined by examining all stems per pot and calculating percentage of infected stems. At maturity stage, grain yield was determined at $14 \%$ moisture content.

Highest Relative lesion height $(\%)=$

Vertical height of uppermost lesion on stem or leaf or sheath $\times 100$ 


\subsection{Lignin Content}

Leaf samples were randomly collected from each pot at 75 DAP and dried in the oven at $60^{\circ} \mathrm{C}$ for $72 \mathrm{hrs}$. Samples were grinded and subjected for 2 steps extraction process for the determination of acid detergent fiber (ADF) and acid detergent lignin (ADL) as reported by [36].

\subsection{Data Analysis}

All data were analyzed using the ANOVA procedure by SAS Statistical software package (version 9.2 for windows). Mean comparisons were conducted using the least significant difference (LSD) test at 0.05 probability level and standard errors of the difference were computed. Arcsine transformation was used in the analysis of the percentage of infected tillers.

\section{Results}

In experimental pots inoculated with $R$. solani, initial symptoms was developed on 10 to $15 \%$ of the stems within 7 to 10 days of inoculation, and these infection levels were within sheath blight treatment thresholds for the varieties in the study. Severe sheath blight developed occurred in the inoculated/untreated (control), averaging 40 to $46 \%$ infected stems with 30 to $44 \%$ of the lesion length to the height of the rice plant. During the growing season, light infestations of sheath blight observed in the non- inoculated experimental pots but did not reached treatment threshold. The main effect of variety and sheath blight inoculation-fertilizer treatment combination had highly significant effects $(\mathrm{P}<0.01)$ on sheath blight incidence; sheath blight severity and rice grain yield (Table 1). The interaction effect between varieties and sheath blight inoculation-fertilizer treatment combination was also significant $(\mathrm{P}<0.05)$ on severity of sheath blight and rice grain yield.

The susceptible variety MR253 showed greater disease incidence and sheath blight severity than the moderately resistant variety MR219 (Table 2). The grain yield of MR219 was significantly $(\mathrm{P}<0.001)$ higher than MR253 as shown in Table 2 . Disease incidence and severity rating were greater for inoculated/untreated (control) compared with non-inoculated and untreated (control) across the varieties (Table 3 ). No significant reduction was recorded among $\mathrm{Si}, \mathrm{Cu}$ and $\mathrm{Zn}$ applications but the least sheath blight incidence and sheath blight severity occurred in Si treatment. Sheath blight incidence was reduced by $23.69 \%$ for $\mathrm{Si}, 18.16 \%$ for $\mathrm{Cu}$ and $13.49 \%$ for $\mathrm{Zn}$ compared to the inoculated control (Table 3). When Si was applied, sheath blight severity was reduced by $17.16 \%$ for MR219 and 29.04\% for MR253 variety compared to the respective control treatments (Figure 1).

The response of grain yield was significantly different among the varieties and also among the sheath blight inoculation and fertilizer treatment combination (Table 4). Although treatment with $\mathrm{Si}$ produced the highest grain yield of 56.20gpot ${ }^{-1}$ and 27.54gpot ${ }^{-1}$ on MR219 and MR253 respectively, the yield response for Zn was less than for both varieties. The lowest grain yield 30.09gpot ${ }^{-1}$ for MR219 and 16.11gpot ${ }^{-1}$ for MR253 were observed in the inoculated and untreated (control) (Table 4).
Compared with the inoculated/ untreated (control) check, application of $\mathrm{Cu}$ increased yield for both varieties.

\subsection{Lignin Content}

Lignin content was significantly $(P=0.05)$ different between MR219 and MR253 rice varieties with silicon treatment. Silicon treatment showed significantly higher lignin content of $6.62 \%$ in variety MR219, and $5.09 \%$ in MR253 compared to the two controls of MR219 (3.60\%) and MR253 (3.33\%). These were also significantly higher compared to $\mathrm{Cu}$ and $\mathrm{Zn}$ treatments (Fig 2). The highest lignin content was followed by the rice plant treated with Zn (5.0\%) for MR219 and (3.72\%) in MR253. The lowest lignin content was recorded in plants treated with $\mathrm{Cu}$ (3.37\%) for MR219. For MR253, the lignin content of $\mathrm{Cu}$ and $\mathrm{Zn}$ treatments were not statistically significant and the minimum lignin content was observed in the control.

\section{Discussion}

With inoculation, incidence of sheath blight disease developed and caused significant grain yield losses for the susceptible rice cultivar (MR253) but not for moderately resistant cultivar (MR219). The difference between noninoculated and the inoculated, untreated controls showed that sheath blight can cause $11 \%$ grain yield loss in MR219 and $50 \%$ grain yield loss in MR253. Similarly, the yield loss were reported to be $8 \%$ in moderately resistant variety and up to $30 \%$ in very susceptible variety by artificial inoculations [37]. Yield loss occurred in the inoculated / control treatment which are typical for heavily infested commercial rice fields. Apparently, MR219 variety is less susceptible and more tolerant than MR253 variety possibly due to their ability to resist lodging when heavily diseased, which is associated with the fungus inability to penetrate the culm [37]. Since genotypes vary in disease resistance, the relationship between Si content among genotypes and disease resistance need to be investigated. According to the reports on rice cultivars grown with highest Si rates [38] sheath blight intensities were greatly reduced compared with cultivars grown in pots not amended with Si.

The grain yield was increased significantly by $\mathrm{Si}$ treatment compared to other treatments. The highest grain yield of 56.2 gpot $^{-1}$ and 27.54gpot ${ }^{-1}$ on MR219 and MR253 varieties respectively was recorded with silicon application. These differences appear to be responsible for the significant-inoculation and fertilizer treatment interaction for this variable. Increased in grain yield was attributed to an increase in the number of grains per panicle [39] and spikelet fertility has been associated with Si concentration in rice [40] (data not sown). When Si was applied, sheath blight severity was reduced by $17.16 \%$ for MR219 and 29.04\% for MR253 variety compared to the respective control treatments. These findings concur with others by [24,25] for disease reduction. Enhanced resistance to disease via Si application can be associated with accumulation of Si in leaf epidermal cells which acts as a mechanical barrier against fungal infestation [23].

Silicon treatment showed significantly higher lignin content of $6.62 \%$ in variety MR219, and 5.09\% in MR253 compared to the two controls of MR219 (3.60\%) and MR253 (3.33\%). These were also significantly higher 
compared to $\mathrm{Cu}$ and $\mathrm{Zn}$ treatments. This finding was in line with other study conducted [41] where Si application had increased lignin content and enhanced activities of the enzymes peroxidase, polyphenol oxidase, and phenylalanine ammonialyase (PAL) in rice leaves infected by rice sheath blight disease. Increased lignification in rice cells was accompanied by silicic acid triggered transcription of genes related to lignin metabolisms [42].

\section{Conclusions}

This study indicated the potential contribution of silicon application in reducing sheath blight disease severity and increasing rice yield. Copper and zinc applications were observed to reduce disease severity and increase yield compared to control. Silicon fertilization could be incorporated as a sustainable and environmentally friendly practice for management of rice sheath blight disease.

\section{Acknowledgements}

The authors of this paper wish to thank the Ministry of Education (MOE), Malaysia for the support of this study by the Long Term Research Grant Scheme (LRGS) received by Universiti Putra Malaysia (UPM) for funding this research and providing technical supports. The first author was supported by a $\mathrm{PhD}$ grant from the Organization for Women in Science for the Developing World (OWSDW) in Italy.

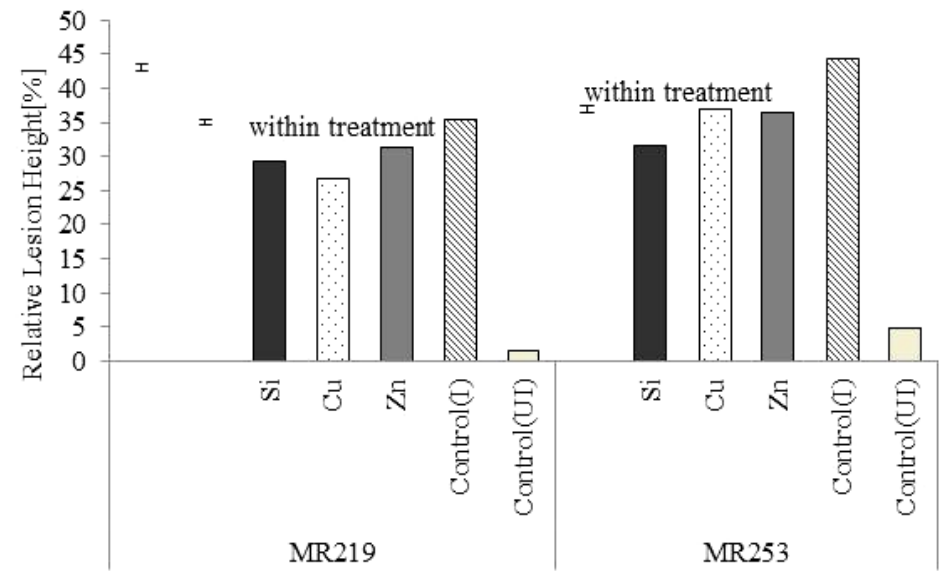

Figure 1. Disease severity in rice plants treated with $\mathrm{Si}, \mathrm{Cu}$ and $\mathrm{Zn}$ after inoculation with Rhizoctonia solani

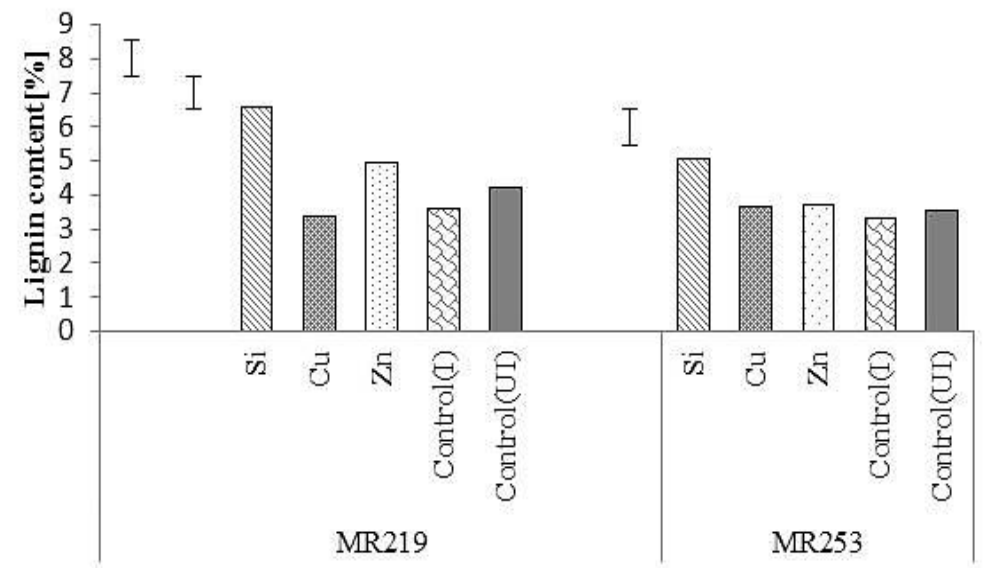

Figure 2. Percentage of acid detergent lignin (ADL) in rice epidermal cells treated with Si, Cu and Zn at 75DAP

Table 1. Significance ( $P$ value) of the main effects of variety and sheath blight inoculation-fertilizer treatment combination (treatment) and interactions among the main effects

\begin{tabular}{|c|c|c|c|}
\hline Effect(df) & Incidence & HRLH & Grain yield \\
\hline Variety(1) & 0.0005 & $<0.01$ & $<0.0001$ \\
\hline Treatment(4) & $<0.0001$ & $<0.0001$ & $<0.01$ \\
\hline Variety x treatment(4) & 0.3104 & $<0.05$ & $<0.01$ \\
\hline
\end{tabular}

Table 2. Effect of varieties on sheath blight incidence, severity and whole rice grain yield ${ }^{\mathrm{a}}$

\begin{tabular}{|c|c|c|c|c|}
\hline Variety & $\begin{array}{c}\text { Sheath blight } \\
\text { Susceptibility }\end{array}$ & $\begin{array}{c}\text { Incidence }^{c} \\
(\%)\end{array}$ & $\begin{array}{c}\mathrm{HRLH}^{\mathrm{d}} \\
(\%)\end{array}$ & 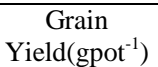 \\
\hline MR219 & MR & $33.37 \mathrm{~b}$ & $24.95 \mathrm{~b}$ & $40.33 \mathrm{a}$ \\
\hline MR253 & MS & $40.85 \mathrm{a}$ & $30.99 \mathrm{a}$ & $24.77 b$ \\
\hline LSD(0.05) & & 5.12 & 2.32 & 3.97 \\
\hline
\end{tabular}

${ }^{\mathrm{a}}$ Means followed by same letter for each parameter are not significantly different at $P=0.05$.

${ }^{\mathrm{b}}$ Sheath blight susceptibility levels included moderately resistant (MR) and moderately susceptible(MS).

${ }^{\mathrm{c}}$ Percentage of stems infected with sheath blight at approximately one week before harvest.

${ }^{\mathrm{d}}$ Highest relative lesion height one week before harvest 
Table 3. Effect of sheath blight inoculation-micronutrient fertilizer treatment combination on sheath blight incidence, highest relative lesion height (HRLH) and whole rice grain yield

\begin{tabular}{cccc}
\hline Inoculation & Treatment & Incidence\% & HRLH\% \\
\hline Non-inoculated & non-treated & $8.33 \mathrm{c}$ & $3.18 \mathrm{c}$ \\
Inoculated & non-treated & $51.42 \mathrm{a}$ & $40.00 \mathrm{a}$ \\
Inoculated & $\mathrm{Si}$ & $39.24 \mathrm{~b}$ & $30.49 \mathrm{~b}$ \\
Inoculated & $\mathrm{Cu}$ & $42.08 \mathrm{~b}$ & $22.21 \mathrm{c}$ \\
Inoculated & $\mathrm{Zn}$ & $44.48 \mathrm{ab}$ & $39.49 \mathrm{a}$ \\
\hline
\end{tabular}

Table 4. Effect of cultivars and sheath blight inoculation-micronutrient application combination on rice grain yield

\begin{tabular}{|c|c|c|c|c|c|c|}
\hline \multirow[b]{2}{*}{ Variety } & \multirow[b]{2}{*}{ Susceptibility ${ }^{\mathrm{y}}$} & \multicolumn{5}{|c|}{ Yield $\left(\text { ghill }^{-1}\right)^{x}$} \\
\hline & & $\begin{array}{c}\text { Non-inoculated/ } \\
\text { non treatment }\end{array}$ & $\begin{array}{c}\text { Inoculated/ } \\
\text { non-treatment }\end{array}$ & $\begin{array}{l}\text { Inoculated/ } \\
\text { silicon }^{\mathrm{z}}\end{array}$ & $\begin{array}{c}\text { Inoculated } \\
\text { Copper }^{z}\end{array}$ & $\begin{array}{c}\text { Inoculated } \\
\text { zinc }^{z}\end{array}$ \\
\hline MR 219 & MR & $33.72 \mathrm{~cd}$ & 30.09 cde & $56.20 \mathrm{a}$ & $44.46 \mathrm{~b}$ & 37.17 bc \\
\hline MR253 & MS & $32.07 \mathrm{~cd}$ & $16.11 \mathrm{f}$ & $27.54 \mathrm{de}$ & $22.50 \mathrm{fe}$ & $22.11 \mathrm{fe}$ \\
\hline
\end{tabular}

${ }^{\mathrm{x}}$ Means followed the same letters are not significantly different at $\mathrm{P}=0.05$.

${ }^{y}$ Sheath blight susceptibility level included moderately resistant (MR) and moderately susceptible (MS).

${ }^{\mathrm{z}}$ Silicon at $(360 \mathrm{~g} / 15 \mathrm{~kg}$ soil $)$, copper at $(0.30 \mathrm{~g} / 15 \mathrm{~kg}$ soil $)$ and zinc at $(0.45 \mathrm{~g} / 15 \mathrm{~kg}$ soil) applied in soil before planting.

\section{References}

[1] Jayaprakashvel, M. and Mathivanan, N., "Morphological and pathological variations of rice sheath blight inciting south Indian Rhizoctonia solani isolates," Archives Phytopathology Plant Protection, 45 (4). 455-467.Oct.2012.

[2] Groth, D.E. (1991).Rice diseases and disorders in Louisiana. Bulletin (USA).

[3] Latif, M.A., Badsha, M.A., Tajul, M.I., Kabir, M.S., Rafii, M.Y., Mia, M.A.T, "Identification of genotypes resistant to blast, bacterial leaf blight, sheath blight and tungro and efficacy of seed treating fungicides against blast disease of rice," Scientific Research and Essays, 6. 2804-2811. 2011.

[4] Marchetti, M.A. and Bollich, C.N., "Quantification of the relationship between sheath blight severity and yield loss in rice," Plant Disease, 75.773-775.1991.

[5] Gangpadyay, S. and Chakrabarti N.K., "Sheath Blight on Rice. Review”, Plant Pathology. 61:451-460. 1982.

[6] Lee, F. N., and Rush, M. C., "Rice sheath blight: A major rice disease," Plant Disease, 67. 829-832.1983.

[7] Zheng, A., Lin, R., Zhang, D., Qin, P., Xu, L., Ai, P. and Li, P., "The evolution and pathogenic mechanisms of the rice sheath blight pathogen," Nature Communications, 4. 1424. Dec.31, 2012. [Online].

Available: http://www.nature.com/ncomms/journal/v4/n1/pdf/ncomms2427.p df. [Assessed Jan. 2013].

[8] Adhipathi, P., Singh, V. and Meena, S. C, "Virulence diversity of Rhizoctonia solani causing sheath blight disease in rice and its host pathogen interaction”, The Bioscan 8(3).949-952. Apr. 2013.

[9] Banerjee, S., Dutta, S., Mondal, A., Mandal, N. and Bhattacharya, S., "Characterization of molecular variability in Rhizoctonia solani isolates from different agro-ecological zones by random amplified polymorphic DNA (RAPD) markers," African Journal of Biotechnology, 11 (40), 9543-9548. April. 2012.

[10] Savary, S. and Mew, T. W. "Analyzing crop losses due to Rhizoctonia solani: rice sheath blight, a case study". In Rhizoctonia species: Taxonomy, molecular biology, ecology, pathology and disease control, Springer Netherlands, 237-245. 1996.

[11] Ho, N.K., Jegatheesan, S. and Phang, F.K, Increasing Rice Productivity in Malaysia-an Independent View. In Hillocks, R.J. and Waller, J.M. Soil borne Diseases of Tropical Crops. CAB International. 2008.

[12] Akinbile, C. O., El-Latif, K. M., Abdullah, R.and Yusoff, M. S. "Rice Production and Water use Efficiency for Self-Sufficiency in Malaysia: A Review", Trends in Applied Sciences Research, 6 (10). 1127-1140. 2011.

[13] Wei, X., Hao, M., Shao, M. and Gale, W. J., "Changes in soil properties and the availability of soil micronutrients after 18 years of cropping and fertilization," Soil and Tillage Research, 91 (1). 120-130.2006. Nov.20005. [On line]. Available on line: www. scientdirect.com/ Volume 91/Number1/. [Accessed Dec. 2006].

[14] Zulkefli, M., Aini, Z., Razak, H. and Kamaruddin, A., "Boron Deficiency in Direct Seeded Rice in KADA Region" in the Proceeding, Soils 2004 Conference. April 2004. Penang, Malaysia. Malaysian Society of Soil Science (MSSS). 2004.

[15] Agrios, G.N. Plant Pathology, $5^{\text {th }}$ Ed. Elsevier Academic Press, Loondon, New York. 2005.
[16] Narayanasamy, P. Microbial plant pathogens and crop disease management. Science Publishers, Inc.Enfield (NH) U.S.A., Plymouth U.K. 2002.

[17] Liew, Y. A., Husni, M. H. A., Zainal, A. M. A., \& Ashikin, N., "Effects of foliar applied copper and boron on fungal diseases and rice yield on cultivar MR219.," Pertanika Journal of Tropical Agriultural Science, 35 (2). 339-349. Nov.2012.

[18] Somani, L.L., Micronutrients for soil and Plant Health, Agrotech Publishing Academy, 14-74. 2008.

[19] Datnoff, L.E. and Rodrigues, F.A., "The Role of Silicon in Suppressing Rice Diseases,” American Phytopathological Society. 2005. [Online].

[20] Bhattacharya, A. and Roy, A.K., "Effect of resistance inducing chemicals in rice (Oryza sativa) against sheath blight under field condition," Indian Journal of Agricultural Science, 71 (2). 139141. 2001.

[21] Ganguli, L. and Sinha, A.K., "Metal salts reduce sheath blight infection of rice,” Journal of Mycopathology Research, 41 (1). 1-6. 2003.

[22] Salam, D., Lakpale, N. and Thrmurty, V.S., "In vitro and in vivo efficacy of micronutrients against Rhizoctonia solani, the cause of sheath blight of rice," Journal of Soils and Crops, 20 (2). 204206.2010.[Online].Available:www.cabdirect.org/Volume20/numb er2/. [Accessed 2010].

[23] Cai, K., Gao, D., Luo, S., Zeng, R., Yang, J. and Zhu, X. "Physiological and cytological mechanisms of silicon induced resistance in rice against blast," Department of Statistic Malaysia.2010, Production of Major Commodities (Updated:30/4/2010). Department of Statistic Malaysia. Oct. 2008.

[24] Rodrigues, F.A. and Datnoff, L.E. "Silicon and rice disease management,” Fitopatologia Braileria. 30 (5). 457-469. Jul. 2005.

[25] Wang Meiqin, "Effect of complete silicon fertilizer on rice yield," Acta Agriculture Shanghai, 21 (1). 71-73. 2005. [Onine]. Available: http://europepmc.org/abstract/CBA/475292/Volume 21/Number1/.[Accessed 2005].

[26] Korndorfer, G., and Lepsch, I. "Effect of Silicon on Plant Growth and Crop Yield”, In Datnoff, L. E., Snyder, G. H. and Korndörfer, G. H. (Eds.) (2001). Silicon in Agriculture. Elsevier, 8: 133-147. 2001.

[27] IRRI (International Rice Research Institute, Nutritional Disorders and Nutrient Management in Rice, International Rice Research Institute Manila, Philippines.2000.

[28] Korayem, A.M., "Effect of Zn fertilization on rice plants on the population of the rice-root nematode," Anzeiger-furSchadlingskunde Pflanzenschutz, Umweltschutz, 66 (1). 18-21. 1993.

[29] Nand, R., and N. Ram, "Amelioration of Zinc stress by farmyard manure in a rice-wheat-cowpea system," Acta-AgronomicaHungarica, 44 (1). 35-39. 1996.

[30] Sagwal, O.P., Vijayrand, K. and Kumar, V., “ Effect of balanced use of fertilizers on productivity of Basnmati rice, Fertilize News, 39(10).55-57.1994.

[31] Selvi, S. and P.P. Ramaswami, "Residual effect of integrated nutrient management in rice-rice-pulse cropping sequence," Madras-Agricultural-Journal, 82 (1). 24-26. 1995.

[32] Singh, A., Prasad, D. and Singh, R., "Management of sheath blight of rice with integrated nutrients," Indian Phytopathology, 63 (1). 11-15. 2010. [Online]. Available: http://epubs.icar.org.in/Volume 63/Number1. [Accessed 2010]. 
[33] Marchner, H.1995. Mineral nutrition of higher plants, $2^{\text {nd }} E d$. Academic Press, London. 1995.

[34] Heitholt, J. J., Sloan, J. J. and MacKown, C. T., "Copper, manganese, and zinc fertilization effects on growth of soybean on a calcareous soil,” Journal of Plant Nutrition, 25 (8). 1727-1740. 2002.

[35] IRRI (International Rice Research Institute), Standard evaluation system for rice. Philippines: International Rice Research Institute, Manila, Philippines. 2002.

[36] Van Soest, P. J., "Collaborative study of acid-detergent fiber and lignin.," Association of Official Analytical Chemists Journal, 56 (4). 781-784. 1973.

[37] Groth, D.E. and Bond,J. A., "Effects of cultivars and fungicides on rice sheath blight, yield and quality," Plant Disease, 91. 16471650. 2007.

[38] Rodrigues, F. A., Vale, F. X. R., Korndörfer, G. H., Prabhu, A. S., Datnoff, L. E., Oliveira, A. M. A. and Zambolim, L., " Influence of silicon on sheath blight of rice in Brazil," Crop Protection, 22 (1), 23-29. 2003. May. 2002. [Online]. Available:
http://www.sciencedirect.com/Volume22/Issue1.

[Accessed Feb.2003].

[39] Khan, A. S., Imran, M. and Ashfaq, M., "Estimation of genetic variability and correlation for grain yield components in rice (Oryza sativa L.)," American Eurasion Journal of Agriculture and Environmental Science, 6 (5). 585-590.2009.

[40] Savant, N.K., Snyder, G.H. and Datnoff, L.E., "Silicon Management and Sustainable Rice Production," Advances in Agronomy, 58:151 -199. 1997.

[41] Zhang, G.,Cui,Y., Ding,X. and Dai,Q., "Stimulation of phenolic metabolism by silicon contributes to rice resistance to sheath blight," Journal of Plant Nutrition and Soil Science, 176. 118-124. Dec. 2012. [Online]. Available: http://onlinelibrary.wiley.com/doi/10.1002/jpln.201200008/abstrac t/Volume 176/. [Accessed Feb. 2013].

[42] Alexander,T.F., Thandar Nye, Repenning, C., Stahl, F. Zahn, M. and Schenk, M.K., "Silicon enhanced suberization and lignification in roots of rice (Oryza sativa)", Journal of Experimental Botany, March; 62 (6). 2001-2011. Nov. 2010. 